\title{
6. National urban policies in the Netherlands: an urban renaissance?
}

\section{Bas Denters}

\section{INTRODUCTION}

During much of its political history the Netherlands combined a high degree of urbanization with a fragmented governance system of cities and provinces in the absence of a dominant centre. Throughout the years of the Dutch Republic (1648-1795), for a number of reasons, cities and local communities played a central role (Kloek and Mijnhardt 2001, p. 42). First, towns and cities commanded at least 50 per cent of the votes in all but one of the state-assemblies in the seven provinces of this republican confederacy. In Holland, the largest and most prosperous of these provinces, the cities even held 18 of the 19 seats in the provincial state assembly (Prak 2018, p. 190). Second, the Dutch Republic did not have a national tax system. It relied on local and provincial taxes for its revenues. Ward officials with firm roots in their local communities, recruited from the local middle class, played a key role in the Republic's decentralized tax collection system (Prak 2018, p. 200). Finally, the elites ruling the Dutch cities were 'under constant pressure from citizens, organized in neighbourhood groups, guilds and civic militias'. These civic organizations 'were routinely involved in shaping local policies, through elections, participation in decisions, petitions and formal and informal meetings with local officials' (Prak 2018, p. 213).

After the French occupation (1795) and the restoration after the Congress of Vienna (1814-1815), this disunited republic was replaced by a much more centralized unitary state under constitutional monarchical rule. In 1848 the Netherlands also introduced representative democracy, and at the same time the constitutional basis for the current decentralized unitary state was created by the liberal lawyer and statesman J. R. Thorbecke (Hendriks and Schaap 2011, p. 122). In Thorbecke's vision the unitary state should be based on 'three active components', that is, central government, the provinces and local authorities (Hendriks and Schaap 2011, p. 122; also see: Toonen 1987). Under this constitution, municipalities - as well as the provinces - enjoyed a constitu- 
tionally guaranteed power of general competence allowing them to do anything they considered in the interest of their residents (unless this conflicted with the legislation of higher authorities). Moreover, the Dutch constitution provided for co-governance, that is, the principle that central government can - and oftentimes actually does - call upon the cooperation of subnational governments in the implementation of national legislation. On the basis of these constitutional principles - that are still in force up to today - municipalities were given a right of initiative, and at the same time are oftentimes involved in the implementation of policies initiated by central or provincial government. This made local governments important partners in a system of intergovernmental relations characterized by overlapping powers and interdependencies, rather than by central command and control (see Denters and Klok 2005; Hendriks and Schaap 2011). This rather more horizontal system of intergovernmental relations was strengthened by a political culture of power-sharing, consensus politics and interest accommodation (Lijphart 1975; Denters and Klok 2005; Hendriks and Schaap 2011).

Urban governance in the Netherlands was also shaped by the pillarization of Dutch politics and society. The life of Dutch citizens - from the late nineteenth century onwards - increasingly took place in the context of one of the so-called 'pillars'. Each of these pillars represented one of the country's major religious or ideological denominations (Lijphart 1975) and comprised a dense network of civic organizations catering - from the cradle to the grave - for those belonging to a particular religious or ideological community. Until the depillarization that started in the late 1960s, these pillarized networks in the cities provided for strong ties between urban political elites, leaders of pillarized civic organizations, and local citizens participating in these organizations (Denters and Klok 2005).

Many of these general characteristics of Dutch government and society have remained remarkably stable over time. Nevertheless, in at least two respects important changes have occurred in the second half of the twentieth century. First, in intergovernmental relations the balance of power has shifted over the years. With the transition from the classic night-watchman state of the nineteenth century to a post-World War II welfare state the initiating role of local governments in the socio-economic domain gradually gave way to a role of a local agent implementing national policy initiatives. This shift was also reflected in the fiscal relations between the central and the local state. Local governments became increasingly dependent on earmarked central government grants rather than on their own local revenues. ${ }^{1}$ Second, the depillarization that had occurred since the late 1960s resulted in a disruption of the traditionally strong ties between the urban political elites, civic organizations and local citizens (Denters and Klok 2005). 
As a consequence, the strong focus of city governments on their local constituencies gave way to an even stronger orientation of urban political elites towards central government in The Hague. National legislation and the strings attached to earmarked grants provided by central government ministries became more important in guiding local governmental decisions than the needs and priorities of local communities (WRR 1990, p. 36). In this respect the Dutch situation in the 1970s and 1980s reflects many features of the welfare model of urban governance (Pierre 1999, pp. 385-389).

With the economic crisis of the 1980s and the ensuing support for neoliberal public sector reform agendas in many Western countries, including the Netherlands, this all began to change. In the wake of the crisis and drastic austerity measures and public sector reforms (including privatizations of public services and decentralizations) the Dutch national government launched a number of important new policy initiatives that had a considerable impact on the governance of Dutch cities in the period between 1990 and 2020.

In this chapter we describe these changes and explore their impact on the governance of the major cities in the Netherlands. Before this, a short description of the current Dutch local government system with a focus on the position of the major cities (section 2) and some of the main challenges facing Dutch cities and city regions (section 3 ) will be provided. This is followed by a chronological discussion of the most relevant national urban policy initiatives (section 4) and an analysis of the main actors that are driving (or preventing) changes in national urban policy initiatives (section 5).

\section{THE CURRENT URBAN GOVERNANCE SYSTEM}

With the introduction of Thorbecke's Municipal Law of 1851 the traditional distinction between urban and rural local governments was abolished. Although current Dutch legislation frequently differentiates between municipalities in terms of population size or other criteria, the Dutch local government - as a default - is based on the principle of uniformity, not differentiating between municipalities as different as Amsterdam (862965 residents) and Schiermonnikoog (936 residents). From a legal perspective the Dutch local governance system is essentially the same for all Dutch municipalities, irrespective of whether geographers or urbanists would consider these municipalities as urban, suburban or rural. In writing a chapter on Dutch national urban policies this poses a problem. It has to be decided which municipalities (or other territorial units - not necessarily being jurisdictions) are to be considered as 'urban'. This is not only a problem facing the author of a chapter like this: policy-makers designing urban policies face a similar definitional problem. Rather than entering into an endless debate on definitional issues, in this chapter the focus pragmatically will be on the largest Dutch municipalities 
(with a population of more than 100000$).^{2}$ And when discussing the various Dutch urban policy initiatives, the focus of the initiative will be a recurrent theme.

The Netherlands is a decentralized unitary state, and as one of the six founding members of the European Economic Community it is firmly embedded in the European Union. In addition to the EU and the national government, this multilevel polity in 2019 comprises 12 provinces and 355 municipalities. ${ }^{3}$ In 2019, 31 Dutch municipalities had more than 100000 residents. In total these municipalities hosted 37 per cent of the national population.

The Dutch constitution provides all municipalities with a power of general competence and allows municipalities - in co-governance arrangements - to play a role in the implementation of a wide range of national policies (see introduction). The national government also provides for a large part of the municipal revenues, through both a general grant (in 2017 amounting to 43 per cent of the total municipal revenues) and numerous specific grants (10 per cent of municipal revenues). ${ }^{4}$

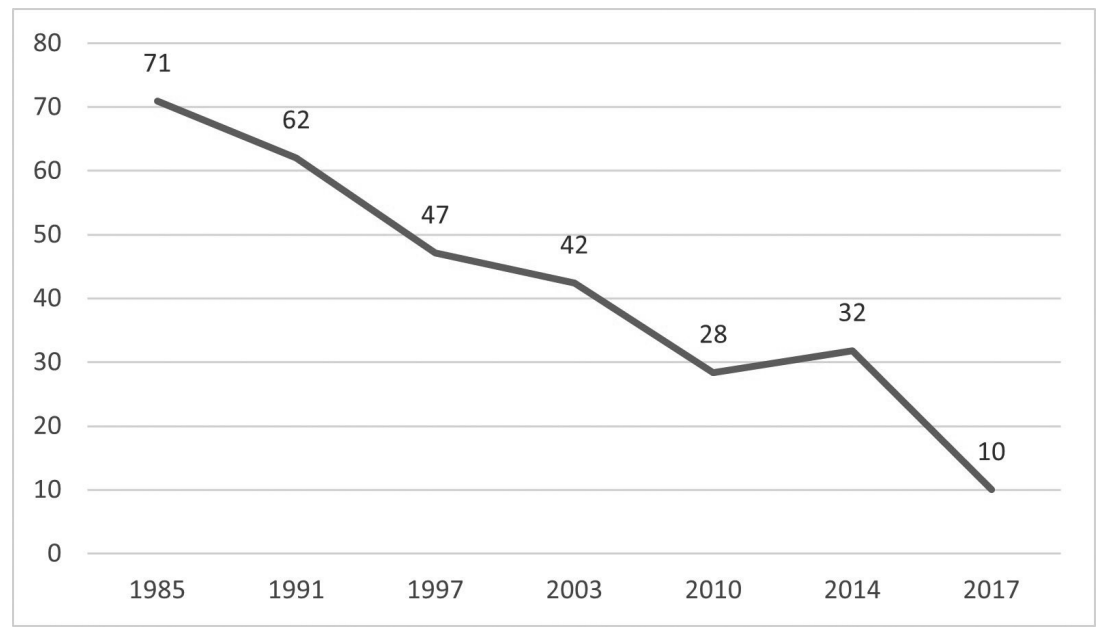

Source: based on Schaap (2015) and BZK (2019).

Figure 6.1 Percentage of revenues Dutch municipalities receive from specific, earmarked grants from central government

As Figure 6.1 shows, the municipal dependence on earmarked central grants has decreased drastically in the last three decades, reflecting cuts by central government in these grants, a transformation of specific into general grants 
(providing municipalities with more discretion in their spending decisions), and higher revenues from purely local sources.

The central government also plays a key role in initiating local government reform policies. These policies can pertain to the institutional make-up of municipal government, as laid out for example in the Municipal Law (as with the introduction in 2002 of new rules to strengthen the position of the municipal council vis-à-vis the mayor and the aldermen), functional reforms (for example the recent decentralizations of social policies) and territorial reforms (for example conditions for intermunicipal cooperation and municipal amalgamations). Both types of territorial reform policies may be relevant from an urban governance perspective (for example as means for coping with the challenges facing territorially fragmented urban regions). Moreover, municipal amalgamations have drastically changed the municipal landscape. Central government's amalgamation policies were a major factor in changing the number and the population size of Dutch municipalities. Between 1980 and 2019 the number of Dutch municipalities was more than halved from 811 to 355 ; in combination with population growth, this resulted in much larger municipalities. In this period the average population size increased from 17375 to 48682 and the number of municipalities with more than 100000 residents grew from 17 to 31 , hosting well over one-third of the country's population. If anything, this has boosted the salience of the national urban policies. The importance of these policies is even further enhanced in the light of a broad range of governance challenges cities are facing.

\section{CURRENT URBAN GOVERNANCE CHALLENGES}

On 14 February 2018 the Dutch national government and representatives of the Dutch provinces, municipalities and waterboards agreed upon a joint Intergovernmental Programme based on a common agenda for dealing with seven major challenges in the physical, the economic and the social domain. With the exception of a common intergovernmental concern with regard to the liveability and vitality of the countryside, all the issues in this programme are highly relevant for the big cities. The six remaining challenges are:

1. Climate mitigation and adaptation, including a 49 per cent reduction in CO2 emissions by 2030 compared with 2018 levels, and including climate change considerations in planning and making a transition to a circular economy.

2. Adapting the housing stock to demographic change (for example ageing population) and increasing opportunities on the housing market for vulnerable groups. 
3. Strengthening regional economies by placing more emphasis on regional conditions for achieving the ambitions of realizing more sustainable and competitive regional economic ecosystems.

4. Improving the life chances and social participation of vulnerable groups (children, people with low literacy, immigrants, multi-problem households) and strengthening the agency of these groups. This includes making extra efforts to tackle loneliness, child abuse and domestic violence as well as dealing with mentally handicapped people.

5. Preventing and resolving the problematic debts of households through, among other things, the early identification of financial problems and by giving municipalities more options to control the costs of debt prevention and management.

6. Dealing with international migration through a more flexible asylum system, a faster return of migrants without residence rights, and improvement of the language level and labour participation of newcomers.

Many of these concerns are particularly relevant for the largest cities. In part this is because of the proportion (about one-third) of the national population living in the 31 largest cities. But for some challenges the big cities are of more than proportionate importance. Challenges regarding energy consumption and climate change are amplified by high population densities and the nature of the built environment in big cities. And large urban conurbations (for example in the Randstad and Brabant) are oftentimes economic accelerators par excellence. Moreover, the big cities are also characterized by a disproportionate concentration of immigrants and are oftentimes also disproportionately confronted with the incidence of social problems like homelessness, loneliness, poverty and debt problems, crime, addiction and poor health. Therefore it is not surprising that, as we will see shortly, several of these challenges over the past 30 years have featured in one or more of the urban policy initiatives of the Dutch national government.

In addition to these substantive challenges, the 2018 Intergovernmental Programme also concluded on a number of principles that would guide the collaborative governance approach to these issues. One of the main principles was providing for good governance and making democracy more resilient by providing for adequate opportunities for direct citizen participation and involvement of decentralized representatives in addressing these major issues. Here too, big cities are likely to experience more problems in providing for adequate citizen involvement and gaining broad public support for the required transformations than small cities. After all, in the big cities of the Netherlands - as compared to in smaller cities and the countryside - levels of social and political involvement, as well as citizens' trust in fellow citizens and their 
confidence in politicians and administrators, are relatively low (see Denters et al. 2014).

\section{NATIONAL URBAN POLICY INITIATIVES BETWEEN 1990 AND 20205}

\subsection{Antecedents}

The economic recessions of the 1970s and 1980s in many countries marked a politico-ideological change. After the post-war dominance of Keynesian social democracy (combining a 'commitment to both economic efficiency and egalitarianism') (Heywood 2007, p. 135), the 1980s witnessed a revival of liberalism, based on a combination of laissez-faire economics and an individualistic and less egalitarian social philosophy (Heywood 2007, pp. 52-53). A similar change occurred in the Netherlands, especially during the Lubbers I and Lubbers II, conservative-liberal (CDA-VVD) cabinets between 1982 and 1989. In this period a number of Grand Operations were implemented to allow for a more lean and mean public sector. These Grand Operations included large-scale reconsideration of (read: cuts in) public spending, privatization of public services, and deregulation. Moreover, these operations also included plans for decentralization of a wide range of policies and public services. Oftentimes these decentralizations were combined with spending cuts, providing municipalities with considerably less than 100 per cent funding for their new tasks (Denters and Klok 2005, p. 72). These decentralization reforms in this period were general and pertained to all Dutch municipalities, urban and non-urban, with the exception of the Problem Cumulation Districts programme introduced in 1983 under the liberal Minister of the Interior Koos Rietkerk (VVD). This policy was based on an integrated approach to the physical decay and social and economic problems in 30 neighbourhoods with large immigrant populations under bilateral collaboration agreements between 18 large and medium-large urban municipalities and central government in The Hague. Notwithstanding its ambitions of an integrated approach, however, the central government's involvement both financially and substantively is largely limited to the Directorate responsible for Minorities Policy (van Putten 2006, p. 17). With the inauguration of a new cabinet in November 1989, the scope and ambitions of national urban policy in the Netherlands changed considerably. 


\subsection{Lubbers III (1989-1994): Social Renewal and Regional Public Authorities}

After two conservative-liberal cabinets, Ruud Lubbers-the Christian-democratic prime minister in the two previous governments - formed a two-party government with the Social Democrats under their party leader Wim Kok. The new CDA-PvdA cabinet made the fight against long-term unemployment and the social inclusion of people long-term dependent on social benefits one of their top priorities. To this end, the new cabinet 'nationalized' an inspiring programme originally developed in the city of Rotterdam. Their 'Sociale Vernieuwing' (Social Innovation) initiative was used as a template for moulding a new approach to the pressing problems of long-term unemployment and dependency on social benefits. Although social problems were not only confined to the cities, many large and medium-large cities in the country had one or more districts with high concentrations of unemployment and poverty. The national Social Renewal Initiative - coordinated by Ien Dales, the social-democratic Minister of the Interior - initially focused on deprived districts in 37 major cities. Later on, under pressure from smaller municipalities and the Association of Dutch Municipalities (VNG), the geographical scale of the national initiative was greatly expanded, in the end including virtually all Dutch municipalities. The Social Renewal Initiative was - just like the preceding Problem Cumulation Districts programme - based on covenants between municipalities and central government. These covenants were based on a general template (identical for all participating municipalities), but this template allowed for amendments proposed by the participating municipalities. With the extension of the initiative to almost all municipalities, however, the room for local adaptations - especially by the smaller municipalities, was rather limited at best. Moreover, the programme also experimented with increasing the spending autonomy of municipalities by replacing a number of earmarked grants by a broad-purpose Social Renewal Grant. This experiment was rather short-lived, but the idea would be resurrected later on.

At the same time as the Social Renewal programme was initiated, the central government also launched initiatives to strengthen the regional governance capacity in seven urban agglomerations. Based on two influential advisory reports, an initiative was launched to gradually establish fully-fledged, directly elected Regional Public Authorities in these regions. These authorities should take the responsibility for the regions' economic development, infrastructure, physical planning, housing and sustainability. The new authorities should replace the viscous, indecisive system of voluntary intermunicipal cooperation, where effective joint action could be delayed or even blocked by a veto from any of the region's municipalities (Denters and Klok 2005). The imple- 
mentation of this initiative was handed over to the new cabinet that was sworn in on 22 August 1994.

\subsection{Kok I (1994-1998): The Urban Policy Initiative (Period 1)}

The new cabinet under the leadership of the social-democratic prime minister Wim Kok was formed by three parties: the Social Democrats (PvdA), the Conservative Liberals (VVD) and the Social Liberals (D66). This cabinet notwithstanding the economic recovery - continued many of the neoliberal policies (cuts in public spending and privatizations) of the previous cabinets under the leadership of the Christian-Democrat Ruud Lubbers. But it combined this approach with the introduction of an ambitious Urban Policy Initiative (UPI I). This UPI (and its follow-up programmes) was an initiative with an explicitly urban focus, where the central government, rather than directly intervening in the cities, aimed at providing the local actors with the conditions to deal with urban challenges (cf. d'Albergo 2010). Together with the intent to establish Regional Public Authorities in the seven most important urban agglomerations, this new initiative should empower the major cities and their local partners to develop a well-integrated strategy for their economic and social development. ${ }^{6}$

This initiative was instigated by a lobby of the four major cities (the so-called G4: Amsterdam, Rotterdam, The Hague and Utrecht). They were frustrated by the very broad substantive scope of the previous urban initiatives and their focus on both large and medium-size cities, and demanded a concerted and well-integrated effort aimed at promoting the economic vitality, safety and liveability of the four major cities. At the same time, a group of 15 medium-large municipalities (the so-called G15) voiced rather similar demands for a national initiative that would also address the problems in their cities. In the new cabinet, a state secretary (the Progressive Liberal Jacob Kohnstamm) was charged with the responsibility for UPI. Initially the new initiative had a narrow focus on the G4 only. The G4 were given new powers along with additional financial means to experiment with new initiatives; for example, they were allowed to establish empowerment or enterprise zones (inspired by similar initiatives in the US and the UK). But already in the first year of its existence the scope of the policy was extended to the G15 and, somewhat later, six more medium-large cities (G6) were also included.

In terms of its governance approach, the new Urban Policy Initiative (UPI) was again based on covenants. But different from the Social Renewal covenants, these agreements were designed by the cities themselves rather than based on a template developed at the Ministry of the Interior. The underlying idea was that the municipalities should be empowered to base the covenant on an integrated local strategy - geared at the local circumstances and reflecting 
differences in local priorities - for strengthening the city's economic vitality, safety and liveability. This strategy was to be developed in close consultation with local residents and economic and societal partners in the local community. An evaluation of the municipal development plans, however, revealed striking similarities (rather than diversity reflecting local differences). In part these similarities (copy \& paste innovations) were the result of the enormous time-pressure under which the local plans had to be developed and pressure exercised by central government ministries. But the lack of local specificities in the plans was also the result of the initial lack in the city administrations of relevant local knowledge and experience and well-established connections with local partners (Denters et al. 1999a, 1999b).

Instigated by the medium-large municipalities, the UPI also experimented with a new auditing system. Inspired by the quality assurance systems used for European universities, the municipal performance would be assessed by an Intergovernmental Peer Review Commission (IPRC). This IPRC would carry out a review, producing recommendations based on self-evaluation and a site visit. Despite repeated demands made by the municipalities in this first UPI period, an integration of the different special grants of various central government ministries into one more general UPI grant was not realized, because of the opposition of several of the ministries. But on the positive side, although no extra money was made available for the UPI through a reallocation of existing budgets to the 25 urban municipalities participating in the UPI, central government allocated about 1.5 billion euros to finance the new initiative (van Putten 2006, p. 132).

All in all, the political climate regarding the UPI was generally favourable at the level of both central and local government, and because of this broad support the initiative was to be continued and further developed under the next Kok II cabinet. Whereas the UPI was generally considered successful, the implementation of the Regional Public Authorities in the seven major urban agglomerations met with increasing resistance. In 1995 the electorates in both Amsterdam and Rotterdam voted down plans for establishing directly elected Regional Public Authorities in these two major agglomerations in the country in (advisory) referendums. After this, the political support, especially within the conservative-liberal coalition partner, for this major regional government reform waned, and plans for the reform of regional governance were ultimately shelved. After this no new attempts at a regional governance reform were attempted. Regional governance from then on had to rely on the instruments for voluntary intermunicipal cooperation (Denters and Klok 2005). 


\subsection{Kok II (1998-2002): The Urban Policy Initiative (Period 2)}

After the general parliamentary elections of 1998, the successful three-party Kok I (PvdA, VVD and D66) cabinet was continued and the UPI programme sustained. In several respects the UPI was even upgraded. Whereas under Kok I a state secretary was responsible, under Kok II the responsibility for UPI II was allocated to a full cabinet minister, the Progressive Liberal Rogier van Boxtel. Moreover, because of the economic recovery, the funding of the UPI was considerably strengthened: during the UPI II period (1998-2004), in total 11 billion euros were allocated to this initiative (van Putten 2006, p. 133) and the spending autonomy of the cities was increased by integrating special grants into fewer, more general-purpose-oriented grants. Finally, five more urban municipalities (G5) were allowed to participate in some parts of UPI II.

The new UPI was based on municipal multi-annual development plans (MDPs). Drafts for the MDPs should be the result of consultations with residents, the local business community and civil society organizations. In this way the MDPs should reflect local priorities and could benefit from the local knowledge of the municipalities and their local partners. Subsequently, the municipalities and central government would have to agree on the final MDP. This MDP - in line with New Public Management maxims - should preferably be stated in terms of measurable performance goals. The municipalities were to be held accountable for achieving the goals set out in the MDPs, and should be free in their strategies for attaining these goals. The audit system (based on intergovernmental peer review) that was introduced by the G15 in the previous UPI period was extended to all participating municipalities. Moreover - as an expression of UPI as an intergovernmental partnership - the role of central government in UP II would also be subjected to intergovernmental peer review. This audit system was also adopted with the aim of strengthening interjurisdictional policy learning, both horizontally between the various cities and vertically between tiers of government. Additionally, a UPI monitor to register intermediate policy results and a Knowledge Centre for Big Cities were established to facilitate intergovernmental policy-learning. In the province of Overijssel, the University of Twente, the provincial government, the five UPI municipalities and private UPI partners of the cities established a similar regional triple-helix-based knowledge institute (KISS). Notwithstanding efforts to strengthen the local targeting of the MDPs, as well as efforts to strengthen local expertise, evaluations of the MDPs - as during the previous period (see Denters et al. 1999a, 1999b) - continued to surprise evaluators because of their remarkable similarities (van der Wouden and de Bruijne 2001).

During this period the UPI was gradually redirected from an essentially city-wide to a more neighbourhood-oriented approach, targeting a limited 
number of deprived neighbourhoods. In due process the focus of UPI also shifted gradually from policies in the economic and physical domain towards social policies aimed at empowering vulnerable families. The ambition of the new minister was to strengthen the economic, social and civic/political participation of the residents in these deprived neighbourhoods.

\subsection{Balkenende I-III (2002-2007): A Continuation of UPI II and the Start of UPI III}

In April 2002 the Kok II cabinet, as a consequence of a major political crisis, resigned. The murder of the populist party-leader Pim Fortuyn (LPF) a few days prior to the ensuing general elections was a major factor in the subsequent electoral landslide. After the elections, the Christian-Democrat Jan-Peter Balkenende became the new prime minister of three short-lived centre-right coalition cabinets. During these three cabinet periods, UPI was continued. For most of this period, responsibility rested with minister Thom de Graaff (D66; who in 2005 was succeeded by his party colleague Alexander Pechtold).

But in the spirit of the centre-right, more than previously, the new cabinet prioritized deregulation and made efforts to reduce red-tape - including in intergovernmental relations. A major breakthrough in 2005 was the integration of all specific central government grants for urban revitalization - totalling 4 billion euros - into three broad grants with increased spending autonomy for city governments: one for economic revitalization, one for social integration and one for physical urban reconstruction. The focus also shifted from making new plans to implementing the previously adopted MDPs, and at the local level major results were achieved in strengthening networks with neighbourhood organizations, civic organizations and the corporate sector. The progressive liberal minister also invested extra funds in experiments to more closely involve residents in the deprived neighbourhoods in co-producing local UPI initiatives. Moreover, via a number of new initiatives (for example the Expert Team Implementation UPI), efforts were made to identify and remove procedures and rules in central government that obstruct, complicate and delay local implementation of UPI plans. Here, procedures were used that signalled the later City Deals. Moreover, the substantive agenda of UPI II (and UPI III that was adopted in the course of 2004) increasingly shifted towards issues of public safety, social deprivation and the integration of immigrants in urban neighbourhoods. During this period the focus of the UPI shifted ever more from the city level to facing such problems at the neighbourhood level. The preparation of UPI III took a long time because, as a consequence of an economic recession, the financial means available for UPI III were cut back considerably (van Putten 2006, p. 134). 
In terms of its governance approach and substantively, however, UPI III did not change much - next to the cutbacks and the establishment of the three integrated grants, perhaps the extension of the network from 30 to 31 urban municipalities in 2006 was the biggest change.

In 2006 minister Pechtold, shortly before the cabinet had to resign proposed using UPI funds to stimulate the social vitality of 56 of the most deprived urban districts. In order to qualify for funding, municipalities would have to develop neighbourhood development partnerships with residents and community organizations.

\subsection{Balkenende IV: Investing in the Social Quality of Selected Urban Neighbourhoods}

In 2007 the fourth Balkenende cabinet was inaugurated. Although the previous prime minister was reappointed, the political composition of the cabinet changed considerably. Balkenende's Christian Democrats (CDA) formed a coalition with the Social Democrats (PvdA) and a small confessional party (CU). During this period the ideas proposed by the Social Liberal minister Pechtold at the end of his term of office (the 56 neighbourhood approach) were further elaborated and became the basis for a new ambitious neighbourhood development programme that initially focused on 40 districts in 18 municipalities. ${ }^{7}$ It was the aim of the ten-year programme to achieve a major breakthrough in the living conditions of the families in these traditionally disadvantaged neighbourhoods. This programme, under the leadership of minister Ella Vogelaar (PvdA), was financed by a highly controversial levy on Dutch social housing associations. The means for this Neighbourhood Action Plan (1 billion euros) came on top of the money already reserved for UPI III.

\subsection{The Rutte Cabinets 2010-2020: From National Investments to City Deals}

In 2010 a new Conservative Liberal cabinet (CDA-VVD, tacitly supported by Wilders' PVV) headed by Prime Minster Mark Rutte (VVD) took office. Up to 2012 the Neighbourhood Action Plan was continued. But then, as a consequence of the coalition's political priorities and the austerity measures introduced after the Great Recession, the new cabinet decided to discontinue the ten-year investment programme after only four years.

In 2010 the Rutte I cabinet terminated the broad grant for economic revitalization and decentralized the two other specific grants. In 2014 the Rutte II cabinet also discontinued the UPI investment programme for physical investments (the broad general grant for physical urban reconstruction). The broad grant for social inclusion was integrated into the general grant and as of 2015 
the main responsibilities for social policies in the Netherlands were transferred to the municipalities. The transfer of responsibilities in this domain went hand in hand with financial decentralization. But central government combined the decentralizations with rather stringent cutbacks on the funding for the decentralized tasks (as compared to the budgets previously allocated for these responsibilities), burdening municipalities with considerable financial risks.

As of 2015 - just 20 years after having launched its UPI initiative - the Dutch national government has for the most part stopped its financial investments in the economic, social and physical revitalization of the cities, after having decentralized the main responsibilities for these programmes to the cities and their local partners. The role of central government, under its current Urban Agenda, is now limited to enabling the cities to develop innovative local programmes. To this end the national government has challenged its urban policy partners to propose a number of City Deals, where central government plays a facilitative role in stimulating urban policy innovations aimed at major societal challenges. ${ }^{8}$ The City Deals, which were instigated by the Dutch Ministry of the Interior, were inspired by similarly named UK initiatives. A City Deal is an agreement 'between a select number of cities, national government departments, civil society and the private sector to tackle a specific and self-defined problem. It acts as a vehicle for cooperation and commitment by mobilizing stakeholders to pool their resources (e.g. financial, legal, expertise) to work together outside of standard operating procedures' (Hamers et al. 2017a, 2017b, 2017c). Different from the UK programme, however, the Dutch City Deals do not involve national funding; as a consequence, City Deals do not normally have a substantial budget of their own. An official evaluation of the programme in 2017 was essentially positive (Hamers et al. 2017a, 2017b, 2017c). According to the evaluators, the national government's role in the City Deals is in principle limited to that of a 'facilitator, participant, broker and inspirer'. They also observe that securing the promising results of some of the City Deals requires investments to 'distribute and upscale knowledge and experience gained in City Deals'. Moreover, the evaluators acknowledge that afterwards, broader implementation of the innovative practices might require 'more substantial funding or regulatory changes ... to accelerate the transition itself' (Hamers et al. 2017a).

On the basis of these positive results, the Rutte III cabinet, inaugurated in October 2017, has also initiated Region Deals. Several of these Region Deals (for example Parkstad Limburg, Twente, Amsterdam, The Hague) primarily focus on issues that are of particular relevance for specifically urban challenges. Contrary to the City Deals, the Region Deals also involve substantial national co-funding. In this respect these Region Deals take a different route towards facing the governance challenges of metropolitan regions: rather than ill-fated previous efforts at structural reform by creating new Regional Authorities, 
THEMES CITY DEALS (https://agendastad.nl/op-weg-naar-city-deals-blog/)

\section{Data infrastructure}

Areas of attention: good national and international digital connections, open data, privacy, competition, security, service innovation

Cross-border economy and labour market

Areas of attention: learning, working and doing business across borders

Urban accessibility (last and first mile)

Areas of attention: modal split, bicycle, car sharing, city distribution, transport, ICT development

Top campuses / innovation environments

Areas of attention: campuses, ecosystem for innovation, business climate

Next economy

Areas of attention: education, labour market, manufacturing, start-ups

Urban transformation

Areas of attention: vacancy, compaction, energy-neutral buildings, facilities level

Circular city

Areas of attention: waste flows, sub-economy, sustainability, resilient cities

Energy transition

Areas of attention: energy networks, energy generation, integration of the living environment, regional profile

Climate adaptation

Areas of attention: integration of climate adaptation and area development

Social inclusion

Areas of attention: efficient social safety net, corporate social responsibility, private financing in the social domain

Healthy city and quality of life

Areas of attention: create a living environment that contributes to health and wellbeing, new care concepts

Figure 6.2 Themes of city deals

these deals are based on stimulating collaborative governance in the face of urgent regional challenges. The network governance approach adopted in the City and Region Deals also provides the main modus operandi for addressing the previously discussed 2018 joint Intergovernmental Programme. 


\section{ACTORS ENGAGED IN NATIONAL URBAN POLICY INITIATIVES}

The introduction of and subsequent changes in Dutch national urban policy initiatives in the period 1990-2020 stem from political interactions between a variety of actors operating at different levels of governance.

Because the focus in this chapter is on national urban policy initiatives, national political and administrative agents are obviously important actors on this stage. As the previous discussion has shown, the initiation of and changes in Dutch national urban policies in the last 30 years have been affected by changes in the political priorities of consecutive central government cabinets. The dominant political persuasion of these cabinets has been an important factor in determining the content of various urban policy initiatives.

In general, over the years, ministers and state secretaries of leftist parties - both Social Liberals (D66) and Social Democrats (PvdA) - have time and again provided important new impulses in the development of the national urban policy. The first fully-fledged, genuinely national urban policy initiative (UPI I) in 1994, for example, was adopted by the Kok I cabinet, under the leadership of a Social Democratic (PvdA) prime minster and a Social Liberal (D66) state secretary. For most of the subsequent period (1994-2010), ministers/state secretaries from these two parties remained in charge of the UPI. ${ }^{9}$

At various stages, the party-political preferences of ministers/state secretaries have also been influential: whereas under Social Liberal leadership UPI initiatives oftentimes focused on innovations of governance (decentralizations, deregulation, local public-private partnerships and participatory governance), Social Democrats tended to aim at strengthening UPI as a social policy programme aimed at improving the life chances of people living in deprived urban neighbourhoods. Although the political support for the UPI predominantly came from these leftist parties, they operated in the context of cabinets oftentimes dominated by centrist and right-wing coalition partners (either Christian Democrats: CDA or Conservative Liberals: VVD, or sometimes both). These partners, with their own priorities, also shaped the UPI policy agenda. Already during the 1980s, the Grand Operations emphasized the need for reconsidering the traditional welfare state and placing greater reliance on private initiatives, decentralization, cutbacks and deregulation. In the past 30 years such priorities have strongly influenced the modus operandi of national urban policies. In the same spirit, the discontinuation under the Rutte cabinets of the UPI and the Neighbourhood Action Plan in the 2010s was based on the presumption that after 25 years of the UPI cities were now well prepared to face their own challenges and, together with their local and regional partners, could henceforth easily dispense with central government's financial support and interference. 
Although the political priorities of coalition cabinets have doubtlessly shaped the national urban policy agenda, the adoption and implementation of national urban policies has also been shaped by bureaucratic politics (Allison 1971; Allison and Zelikow 1999). In particular, the decentralization of competencies and financial means to the city governments was met with sometimes fierce resistance from specialist central government departments (for example housing, economic development and social policy). In the early years of the UPI, central government bureaucrats were heavily involved in the negotiations of the covenants between national and city governments (see for example van der Laan et al. 1998) and in formulating the performance targets for multi-annual development plans (MDPs) and other local plans. Moreover, opposition from specialist departments - oftentimes supported by professional national interest groups and sympathetic parliamentarians - also complicated and delayed the integration of numerous specific central grants into one or a few general purpose grants as well as the deregulation of such grants, allowing the cities more spending autonomy.

In addition to major actors in central government, various subnational actors were also involved in the adoption and implementation of the UPI and other national urban policies. Over the years, the role of the national Association of Dutch Municipalities (VNG) has been relatively minor. As an association that should stand for the common interests of all Dutch municipalities, the VNG always finds itself in an awkward position when arguing for the concerns of a particular group of municipalities (here the big cities). Therefore, on such issues the VNG oftentimes prefers to keep a low profile or concentrate on non-controversial topics. Rather than the VNG, a lobby organization of the four largest cities (Amsterdam, Rotterdam, The Hague and Utrecht; G4) played an especially important role in the initiation and further development of many of the national urban policy initiatives. An intensive lobbying campaign by the G4 - headed by the social-democratic mayors of Amsterdam and Rotterdam - at the time of the formation of the Kok I cabinet was crucially important for the adoption of UPI I. Moreover, because of their good contacts with members of the cabinet, MPs and central government ministries, the views and interests of these cities were generally well represented in the creation and implementation of national urban policy initiatives (van Putten 2006). Shortly after the announcement of UPI I, a group of medium-large municipalities also decided to organize themselves in order to argue for the interests of their cities. At first, this was limited to 15 municipalities (G15), but gradually this group expanded to its current size of 40 members (G40). This expansion reflects the successful lobbying of medium-sized municipalities to be included in the UPI (and later national initiatives focusing on the urban neighbourhood level) and their increased capacity to represent their citizens' interests at the national level. Although this might - justifiably - be framed as a positive development, the 
G4 in particular have pointed to the consequent loss of focus and specificity of national urban policies (like the UPI and the neighbourhood approach). ${ }^{10}$

On matters of the UPI, the Dutch provinces, for the most part, have kept a low profile. But regarding the issue of the governance of urban regions, the provinces have played a more active role. When, for example, during the Kok I cabinet plans were prepared to establish seven new Regional Public Authorities (to be split off from one of the existing provinces), there was active provincial lobbying against this initiative (see for example Boedeltje and Denters 2010).

The role of the EU in the development of national urban policy initiatives has been rather limited. The Dutch UPI was developed domestically. Its start more or less coincided with the preparations for a European Urban Community Initiative, leading to the URBAN II programme in 2000. After 2000, several Dutch UPI cities have benefitted from funds provided by the European Regional Development Fund and by URBAN II, and required co-financing was often provided by Dutch UPI funds (van Putten 2006, pp. 60-61). Rather than being influenced by EU urban policy initiatives, the Dutch Ministry of the Interior has used its EU Presidency in both 2004 and 2016 - based on previous UPI experiences - to provide new impulses to EU urban policy initiatives. In 2004 the Dutch Presidency pointed to the crucial role of cities as engines of social and economic development, and the need to link initiatives that aim at strengthening the economic potential of cities and addressing the significant social problems in urban areas. In light of this, the Dutch Presidency pushed for the creation of an EU framework and the establishment of a European Urban Knowledge Network (van Putten 2006, pp. 75-76). In 2016 the Dutch Presidency was used once more as a forum for concluding the Pact of Amsterdam aimed at creating a new EU Urban Agenda. As a highly urbanized country, the Netherlands has felt that a more urban focus of EU policies might be beneficial for the country. This Dutch call for the EU to pay more attention to urban issues has become more influential, as in recent years there has been an increasing awareness that increasing territorial cohesion and reducing socio-economic gaps requires more urban-friendly EU policies. In this spirit, the Pact advocates a multilevel/multi-actor approach in which various stakeholders, on the basis of partnerships, address major urban challenges. The approach outlined in this pact is to a large extent based on Dutch experiences with its domestic City Deals initiative. ${ }^{11}$ Both before and after 2016 the Dutch approach to City Deals received quite a bit of international attention. For example, in 2019 the Dutch programme received the European Best Practice Certificate from the jury of the European Public Sector Awards (EPSA). 


\subsection{Specific Policies}

In addition to explicitly urban policies (like the UPI and the City Deals) and indirect policies aimed at strengthening the governance capacity of (urban) municipalities and regions (like the ill-fated efforts to establish Regional Public Authorities in the early 1990s), the Dutch national government has also produced impacts on the physical and socio-economic conditions in urban areas through numerous specific policies that are not explicitly urban (cf. d'Albergo 2010). ${ }^{12}$

In the context of this chapter one might consider at least four types of specific policies:

1. Policies aimed at economic development

2. Policies aimed at the regeneration of towns and cities

3. Policies aimed at social welfare and social inclusion (including policies aimed at the integration of immigrants)

4. Policies aimed at public safety and security.

Before the UPI, these different specific policies were developed by the different separate national government ministries without much inter-ministerial coordination. In 1994 these policies were included in the UPI and as a consequence the UPI cities were increasingly able to negotiate a bilateral agreement with central government. To a certain extent, this allowed them to gear these national specific policies to meet local needs and local priorities. During the different generations of the UPI, the opportunities for the city governments to gear these specific policies to local circumstances were gradually increased, especially when the many specific central grants for most of the policies in these four domains were integrated into only three broad specific grants, allowing the cities considerable spending autonomy. In the last decade the funding for local economic policies and the regeneration of towns and cities were discontinued (in 2010 and 2015 respectively) and the funds for local social policies and integration were integrated into the general grant (where municipalities are free to determine their spending priorities) that all municipalities receive.

\section{CONCLUSIONS: WHAT ROLE (IF ANY) IS THERE FOR NATIONAL GOVERNMENT IN URBAN AFFAIRS?}

In our introduction we indicated that, historically, the responsibility for social, economic and physical living conditions in Dutch cities largely rested with city governments together with local residents and corporations and civic organi- 
zations in the local community. During the twentieth century, and especially after World War II, the role of city governments in determining prosperity and well-being in the cities gradually declined. In this chapter we have seen that, especially during the 1990s as part of the UPI, this trend has been reversed.

At that time it was increasingly recognized (for example WRR 1990) that in a highly urbanized country like the Netherlands, and in an ever more competitive global economy, the social and economic welfare of the country was highly dependent on the vitality of its big and medium-large cities. To exploit the economic potential and to cope with urban issues (social deprivation, safety, health, pollution, congestion and decay) the creation of urban development strategies was considered crucially important. To be effective these strategies had to (1) be adapted to differences in local circumstances (in terms of both potentials and problems) and (2) be based on local partnerships between the public sector, residents and corporate and third-sector organizations. In both respects the city governments were considered much better able to develop effective urban development strategies than the central government based in The Hague.

After decades of centralization during the post-war reconstruction and the establishment of the modern welfare state (see introduction), this implied a reconsideration of the role of the national government. There was an increasing consensus that the Dutch state had become far too centralized (for example WRR 1990). Rather than dictating the terms for urban revitalization, central government should empower city governments to exploit local opportunities and face the problems in their cities. As part of a gradual transition, city governments should assume an ever more prominent role in determining the future of their city. Initially, this would have to be done in close collaboration with the various central government departments in The Hague (with all their expertise and their financial resources). But it was the proclaimed aim of the various UPI programmes to shift the balance from the centre towards the cities (see the discussion of the UPI). And it was precisely because of this that the national urban policy initiative in the 1990s was designed as an explicitly urban policy based on an indirect approach (using the terminology proposed by d'Albergo 2010). Rather than making direct interventions, central government in those years opted for a co-governance approach aimed at empowering city governments and their local and regional partners to develop effective strategies for urban revitalization (cf. d'Albergo 2010).

In the mid-2010s, it was argued - at least by the then ruling centre-right coalition cabinet - that as a consequence of the continuous investments made during the UPI era and the large decentralizations that had been implemented since the 1980s, city governments were sufficiently well-equipped to take full responsibility for the social and economic development of their cities. On the basis of this, the large urban investment programmes were discontinued 
and the central government took on a different role (purely facilitation, brokerage and knowledge dissemination and management) - as in the current City Deal initiative. Whether such a more distant role in dealing with the new urban challenges as they were defined in the recent Intergovernmental Programme (2018) can dispense with new additional funding for local and regional initiatives remains to be seen..$^{13}$ But, more than three decades on, it is now generally recognized that in the multilevel urban governance system that exists in the Netherlands, city governments and local communities are key players in facing the grand challenges of this highly urbanized country (cf. the Intergovernmental Programme and other recent decentralizations). In this sense one might indeed say that the Netherlands in recent years has witnessed something of an urban renaissance. At the same time, however, there is also considerable debate as to whether local governments are always well-equipped to take on these exacting new responsibilities, partly because central government does not provide adequate finances, but also because at the local level there is not always sufficient expertise and governance capacity available to innovate and adequately gear policies to local circumstances (as the experiences during the UPI era demonstrated).

\section{NOTES}

1. In 1985 these specific grants amounted to 70.9 per cent of local revenues, with 21.9 per cent coming from the general grant and a mere 7.2 per cent from local taxes and other local revenues (Schaap 2015, p. 121).

2. From a scientific perspective this is unsatisfactory because population size is but one of the dimensions of urbanity. But in a highly urbanized country such as the Netherlands, most but not necessarily all the largest municipalities are likely to be more or less urban by other standards. In the political arena this typically resulted in debates on the inclusion of particular municipalities (or regions defined otherwise).

3. In terms of competences and finances the conditions for urban governance are primarily determined by the Dutch national government. With the exception of regulating forms of intermunicipal cooperation, the role of the provinces in urban governance is limited (although a few of them have experimented with provincial urban policy programmes). Therefore, this contribution focuses on the role of the national government.

4. Data are taken from BZK (2019). The general grants include two types of temporary grants for funding recent decentralizations in the social domain that are, strictly speaking, not earmarked and will in the near future be integrated into the regular general grant that is distributed via the Municipalities Fund. For a description of the system, see RFV (2009).

5. This section builds heavily on the very useful history of national urban policy in the Netherlands up to 2006 by Nico van Putten (2006), and on Gastkemper et al. (2019) that also covers more recent years.

6. In terms of d'Albergo's typology (2010), this policy initiative can be classified as an indirect national urban policy, which was initially framed as an explicitly 
urban initiative (because of its focus on urban metropolitan regions only). Later on, however, the focus was extended, and the introduction of Regional Public Authorities was also proposed for the non-urban regions. As a consequence of this the opposition against the introduction of these new public authorities became even stronger, and in the light of this resistance these plans were abandoned altogether.

7. Later, 37 districts were added to the programme, involving 32 additional municipalities.

8. Notwithstanding the differences with the previous UPI approach, the City Deals approach again is an explicit and indirect approach to national urban policy making (cf. d'Albergo 2010).

9. There were two short periods (2002-2003 and 2006-2007) during which the responsibility for this policy domain rested with a Conservative Liberal.

10. At the intra-municipal level the UPI and the neighbourhood action initiatives engage a host of other corporate actors and third-sector organizations as well, and many cities have also involved residents, either on an individual basis or via organizations of residents. The nature of these local partnerships varies across municipalities. A description of this variety - if at all possible - is beyond the scope of this chapter, which focuses primarily on the national level.

11. See Pact of Amsterdam, https://ec.europa.eu/regional_policy/sources/policy/ themes/urban-development/agenda/pact-of-amsterdam.pdf.

12. These policies are general rather than directly aimed only at urban areas. Often, these implicitly national urban policies - although aimed at particular policy domains like public safety, social inclusion or the physical living environment and not purely institutional - are still to be considered indirect because the national government specifies the conditions for municipalities to adopt local policies. These conditions may allow for more or less local discretion.

13. Central government seems to recognize the need for additional funding of subnational initiatives as in the recent Region Deals it does make additional funding available for local and regional programmes.

\section{REFERENCES}

Allison, G. T. (1971), The Essence of Decision: Explaining the Cuban Missile Crisis, Boston, MA: Little, Brown and Company.

Allison, G. T. and P. Zelikow (1999), The Essence of Decision: Explaining the Cuban Missile Crisis (second ed.), New York: Longman.

Boedeltje, M. and B. Denters (2010), 'Step by step: Territorial choice in the Netherlands', in H. Baldersheim and L. E. Rose (eds), Territorial Choice: The Politics of Boundaries and Borders, Houndmills: Palgrave Macmillan, pp. 118-137.

BZK (2019), 'Staat van het Bestuur 2018', accessed 29 June 2020 at https://k ennisopenbaarbestuur.nl/rapporten-publicaties/staat-van-het-bestuur-2018/.

d'Albergo, E. (2010), 'Urban issues in nation-state agendas: A comparison in Western Europe', Urban Research and Practice, 3 (2), 138-158.

Denters, B. and P.-J. Klok (2005), 'The Netherlands: In search of responsiveness', in B. Denters and L. E. Rose (eds), Comparing Local Governance: Trends and Developments, Houndmills: Palgrave Macmillan, pp. 65-82. 
Denters, B., G. Mike, A. Ladner, P. E. Mouritzen and L. E. Rose (2014), Size and Local Democracy, Cheltenham, UK and Northampton, MA, USA: Edward Elgar Publishing.

Denters, B., O. v. Heffen and H. de Jong (1999a), 'An American Perestroika in Dutch cities? Urban policy in the Netherlands at the end of a millennium', Public Administration, 77 (4), 837-853.

Denters, S. A. H., O. v. Heffen and H. M. de Jong (1999b), 'Het grotestedenbeleid: proeftuin of Procrustusbed?', Bestuurskunde, 8, 106-115.

Gastkemper, N., M. Uyterlinde and J. v. d. Velden (2019), 'Zeventig jaar stedelijke vernieuwing, Longread kennisdossier Stedelijke vernieuwing, Update 2019', accessed 29 June 2020 at https://www.platform31.nl/uploads/media_item/media_item/121/ 54/Kennisdossier_stedelijke_vernieuwing_update_2019_def-1553545877.pdf.

Hamers, D., M. Dignum and D. Evers (2017a), Evaluatie City Deals accessed 29 June 2020 at https://www.pbl.nl/sites/default/files/downloads/pbl-2017-evaluatie-city -deals-2915_1.pdf.

Hamers, D., M. Dignum and D. Evers (2017b), Evaluatie City Deals - Vervolg, accessed 29 June 2020 at https://www.pbl.nl/sites/default/files/downloads/pbl-2017 -evaluatie-city-deals-vervolg-3015.pdf.

Hamers, D., M. Dignum and D. Evers (2017c), Fact Sheet: Dutch City Deals Evaluation - Follow-Up, accessed 29 June 2020 at https://www.pbl.nl/sites/default/ files/downloads/Factsheet_PBL_City_Deals_Evaluation.pdf.

Hendriks, F. and L. Schaap (2011), 'The Netherlands: Subnational democracy and the reinvention of tradition', in A. Lidström, F. Hendriks and J. Loughlin (eds), The Oxford Handbook of Local and Regional Democracy in Europe, Oxford: Oxford University Press, pp. 96-122.

Heywood, A. (2007), Political Ideologies: An Introduction, London: Macmillan Education.

Kloek, J. and W. Mijnhardt (2001), 1800: Blauwdrukken voor een samenleving, The Hague: Sdu Uitgevers.

Laan, F. v. d., H. A. P. v. Aart, S. A. H. Denters, H. S. Halbersma, O. v. Heffen and H. M. de Jong (1998), Wondermiddelen zijn niet voorhanden; Grote-stedenbeleid 1995-1997: gemeentelijke beleidsruimte en de benutting daarvan, Delft: Eburon.

Lijphart, A. (1975), The Politics of Accommodation: Pluralism and Democracy in the Netherlands. Berkeley, CA: University of California Press.

Pierre, J. (1999), 'Models of urban governance: The institutional dimension of urban politics', Urban Affairs Review, 34 (3), 372-396.

Prak, M. (2018), Citizens without Nations: Urban Citizenship in Europe and the World, 1000-1789, Cambridge: Cambridge University Press.

Putten, N. v. (2006), Terug naar de stad. Een kleine geschiedenis van het grotestedenbeleid, Leiden: De Bink BV/BZK.

RFV (2009), 'The municipality and its finances. Introduction to the financial relations between central government and the municipalities in the Netherlands', accessed 29 June 2020 at https://www.raadopenbaarbestuur.nl/documenten/publicaties/2009/02/ $02 /$ the-municipality-and-its-finances.

Schaap, L. (2015), Lokaal bestuur, Dordrecht: Convoy Uitgevers BV.

Toonen, T. A. J. (1987), Denken over binnenlands bestuur: theorieën van de gedecentraliseerde eenheidsstaat bestuurskundig beschouwd, 's-Gravenhage: VUGA.

Wouden, R. v. d. and E. d. Bruijne (2001), De stad in de omtrek: problemen en perspectieven van de vier grotstedelijke gebieden in de Randstad, The Hague: Sociaal en Cultureel Planbureau. 
WRR (1990), Van de stad en de rand, 's-Gravenhage: SDU uitgeverij. 